KOMPASS

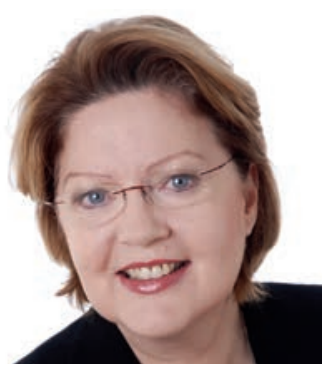

Prof. Dr. Regina Fölster-Holst

Klinik für Dermatologie, Venerologie und Allergologie, Universitätsklinikum SchleswigHolstein, Campus Kiel
Karger Kompass Dermatol 2017;5:94-95

DOI: 10.1159/000453563

\title{
Besonderheiten bei atopischem Ekzem in der frühen Kindheit
}

\author{
Ausgewählt und kommentiert von \\ Prof. Dr. Regina Fölster-Holst (Kiel)
}

Das atopische Ekzem (AE) ist die häufigste chronische Erkrankung im frühen Kindesalter, die sich meist bereits im ersten Lebensjahr manifestiert. Mit der Nahrungsmittelallergie steht das AE am Anfang des «atopischen Marsches».

Die Morphologie und die Prädilektionsstellen des infantilen AE unterscheiden sich von denen der älteren Kinder und Erwachsenen: Gesicht, Hals und Extremitätenstreckseiten sind betroffen. Auffällig ist die starke exsudative Note im Gesicht und im Bereich des Capillitium. Nicht selten manifestiert sich das infantile AE als nummuläres Ekzem, wobei sowohl die «trockene» als auch die «feuchte» Form vorkommt.

Neben den altersunabhängigen Differentialdiagnosen von Ekzemerkrankungen (Kontaktekzeme, seborrhoisches Ekzem) und Skabies sind Genodermatosen (u.a. Netherton Syndrom, generalisiertes Peeling-Skin-Syndrom), Immundefektsyndrome (u.a. Di GeorgeSyndrom, Omenn-Syndrom, Wiskott-Aldrich-Syndrom), Stoffwechselerkrankungen (u.a. Acrodermatitis enteropathica, Biotinidasemangel, Phenylketonurie) und auch proliferative Erkrankungen wie Langerhanszell-Histiozytosen differentialdiagnostisch zu bedenken. Weitere Besonderheiten in dieser Lebensphase des frühen Kindesalters betreffen die Provokationsfaktoren (vor allem Nahrungsmittelallergien), die Therapie (meist Off-Label-Use) sowie Defekte des Immunsystems und der epidermalen Barriere.

Bereits bei gesunden Neugeborenen ist ein Anstieg des transepidermalen Wasserverlustes (TEWL), der ein Maß für die intakte Funktion der epidermalen Barriere darstellt, von Geburt bis zum Ende des Neugeborenenalters zu verzeichnen. Die Reifung der epidermalen Barriere ist erst nach der Säuglingszeit abgeschlossen. Kürzlich konnten Berents et al. die Ergebnisse einer früheren Studie bestätigen, nach der ein erhöhter TEWL, gemessen am zweiten Lebenstag sowie im Alter von zwei Monaten, ein Prädiktor für das AE im weiteren Verlauf darstellt. Jedoch waren die Spezifität, die Sensitivität und der positive prädiktive Wert des erhöhten TEWL niedrig. Das könnte auf die von den Autoren angegebenen Limitationen der Studie (u.a. Kleine Kohorte, unterschiedliche Untersucher, große Unterschiede in der Umgebungsfeuchtigkeit) zurückgeführt werden.

Neben der epidermalen Barriere lassen sich auch Defekte des Immunsystems bereits in der infantilen Phase des AE feststellen. Altersunabhängig gehört auch die Prädominanz der

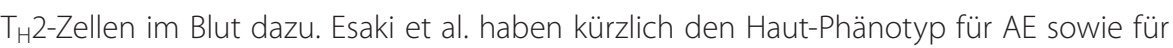
Psoriasis im Kindes- und Erwachsenenalter mittels immunhistochemischer- und PCRUntersuchungen verglichen. Läsional ließ sich bei Kindern eine mit den erwachsenen Patienten vergleichbare oder stärkere epidermale Hyperplasie feststellen.

\section{KARGER}

() 2017 S. Karger GmbH, Freiburg

Fax +497614520714

information@karger.com

www.karger.com 
Auch bei früher Manifestation, der Initialphase des $A E$, steht die Aktivierung der $T_{H} 2$ - und der $T_{H}$ 22-Zellen im Vordergrund.

Überrascht hatte die im Vergleich zu den erwachsenen Patienten signifikant stärkere Aktivierung der $T_{H} 9$ - und $T_{H}$ 17-Zellen, die sowohl in läsionaler als auch in nicht-läsionaler Haut des AE bei Kindern nachweisbar war. Die Ergebnisse sind für die Autoren Anlass genug, eine frühe systemische Intervention zu diskutieren.

\section{Berents TL, Lødrup Carlsen KC, Mowinckel P, et al.:}

Transepidermal water loss in infancy associated with atopic eczema at 2 years: a population-based cohort study. Br J Dermatol 2016;DOl:10.1111/bjd.15157.

Skin barrier function can be evaluated by measuring transepidermal water loss (TEWL). High TEWL is found in children with atopic eczema (AE) and in infants with a mutation in the gene encoding for profilaggrin, a precursor for filaggrin, an important protein for skin barrier function. In a recent study by Kelleher et al., high TEWL at 2 days and 2 months preceded and predicted $\mathrm{AE}$ at 1 year, independent of parental atopy and filaggrin mutation status.

\section{Esaki H, Brunner PM, Renert-Yuval Y, et al.: Early-onset pediatric atopic dermatitis is $\mathrm{T}_{H} 2$ but also $\mathrm{T}_{H} 17$ polarized in skin. J Allergy Clin Immunol 2016;138:1639-1651.}

Background: Atopic dermatitis (AD) affects $15 \%$ to $25 \%$ of children and $4 \%$ to $7 \%$ of adults. Paradigm-shifting discoveries about AD have been based on adult biomarkers, reflecting decades of disease activity, although $85 \%$ of cas- es begin by 5 years. Blood phenotyping shows only $\mathrm{T}_{\mathrm{H}} 2$ skewing in patients with early-onset pediatric $\mathrm{AD}$, but alterations in early pediatric skin lesions are unknown, limiting advancement of targeted therapies.

Objective: We sought to characterize the early pediatric AD skin phenotype and its differences from pediatric control subjects and adults with AD.

Methods: Using immunohistochemistry and quantitative real-time PCR, we assessed biopsy specimens from 19 children with AD younger than 5 years within 6 months of disease onset in comparison with adults with AD or psoriasis and pediatric and adult control subjects.

Results: In lesional skin children showed comparable or greater epidermal hyperplasia (thickness and keratin 16) and cellular infiltration (CD3 ${ }^{+}$, $\mathrm{CD}_{11 \mathrm{c}^{+} \text {, and } \mathrm{Fc \varepsilon RI}}{ }^{+}$) than adults with AD. Similar to adults, strong activation of the $\mathrm{T}_{\mathrm{H}} 2$ (IL-13, IL-31, and CCL17) and $\mathrm{T}_{\mathrm{H}} 22$ (IL-22 and S100As) axes and some $\mathrm{T}_{\mathrm{H}} 1$ skewing (IFN- $\gamma$ and CXCL10) were present. Children showed significantly higher induction of $\mathrm{T}_{\mathrm{H}}$ 17-related cytokines and antimicrobials (IL17A, IL-19, CCL20, LL37, and peptidase inhibitor 3/elafin), TH9/IL-9, IL-33, and innate markers (IL-8) than adults $(\mathrm{P}<0.02)$. Despite the characteristic downregulation in adult patients with $\mathrm{AD}$, filaggrin expression was similar in children with $\mathrm{AD}$ and healthy children. Nonlesional skin in pediatric patients with AD showed higher levels of inflammation (particularly IL-17A and the related molecules IL-19 and LL37) and epidermal proliferation (keratin 16 and S100As) markers $(\mathrm{P}<0.001)$.

Conclusion: The skin phenotype of new-onset pediatric AD is substantially different from that of adult AD. Although excess $\mathrm{T}_{\mathrm{H}} 2$ activation characterizes both, $\mathrm{T}_{\mathrm{H}} 9$ and $\mathrm{T}_{\mathrm{H}} 17$ are highly activated at disease initiation. Increases in IL-19 levels might link $\mathrm{T}_{\mathrm{H}} 2$ and $\mathrm{T}_{\mathrm{H}} 17$ activation. 